\title{
Reportażowa saga rodzinna. Fuzja gatunków i dziennikarska archiwistyka
}

„Wszystkie szczęśliwe rodziny są do siebie podobne, każda nieszczęśliwa rodzina jest nieszczęśliwa na swój sposób”1

Lew Tołstoj, Anna Karenina

\begin{abstract}
ieszący się obecnie niesłabnącym zainteresowaniem reportaż jest formą stale ewoluującą i wytwarzającą wciąż nowe, hybrydyczne odmiany gatunkowe. Jedną z nich jest reportażowa saga rodzinna, łącząca w sobie dziennikarską rzeczowość oraz sprawozdawczość z literackim mitologizowaniem przeszłości. W ostatnich latach na polskim rynku wydawniczym pojawiło się wiele książek reportażowych, których tematyka ogniskuje się wokół historii rodzinnej autora, drobiazgowo odtworzonej na podstawie osobistych pamiątek, wspomnień, archiwalnych dokumentów czy dawnych informacji prasowych. W niniejszym szkicu przedmiotem zainteresowania będą dwa tomy, które bardzo wyraźnie zbliżają się do siebie zarówno pod względem omawianej problematyki, jak i sposobu jej prezentowania. Fałszerze pieprzu Moniki Sznajderman ${ }^{2}$ oraz Dom $z$ dwiema wieżami Macieja Zaremby Bielawskiego ${ }^{3}$ to książki, które wykazują silne międzygatunkowe inspiracje i jako takie wyznaczają pewien osobny nurt pisarstwa non-fiction zasadzający się na reporterskiej rekonstrukcji i osobistym zaangażowaniu autora.
\end{abstract}

\footnotetext{
Dr Edyta Krystyna Żyrek-HorodysKa - Uniwersytet Jagielloński, Wydział Zarządzania i Komunikacji Społecznej, Instytut Dziennikarstwa, Mediów i Komunikacji Społecznej, Zakład Komunikowania Międzynarodowego i Mediów, e-mail: edytazyrek@wp.pl, ORCID: 0000-00027276-1736.

1 L. Tołstoj, Anna Karenina, tłum. K. lłłakowiczówna, Warszawa 1965, s. 5.

2 Por. M. Sznajderman, Fałszerze pieprzu. Historia rodzinna, Wołowiec 2016.

3 Por. M. Zaremba Bielawski, Dom z dwiema wieżami, tłum. M. Kalinowski, Kraków 2018.
} 
Celem artykułu jest przedstawienie reportażowej kroniki rodzinnej jako struktury formalnie niezdyscyplinowanej, łączącej w sobie elementy powieści rodzinnej, autobiografii, eseju oraz reportażu. Jej cechą charakterystyczną jest dokonywana przez piszącego eksploracja widmowej przeszłości, do której dostęp zapośredniczony został poprzez dziennikarskie (dokumenty, archiwa, korespondencja) i pozadziennikarskie (pamięć, pogłoski, wyobraźnia) źródła informacji. Tomy autorstwa Sznajderman i Zaremby Bielawskiego to prace przynoszące obraz bezpowrotnie utraconego świata i generujące nostalgiczną tęsknotę za idylliczną rzeczywistością sprzed Zagłady. Autorzy, dokonując drobiazgowej rekonstrukcji swej historii rodzinnej, włączają ją w zdecydowanie szerszy kontekst aktualnych dyskusji na temat inności czy rozmaitych form społecznego wykluczenia. Sięgając po narzędzia parabolizacji historycznego dyskursu, pokazują przy tym, jak uniwersalną i pojemną formą pozostaje reportaż, który obecnie znacząco redefiniuje dziennikarski paradygmat aktualności i udatnie łączy nostalgiczny przekaz biograficzny $\mathrm{z}$ ukształtowaną $\mathrm{w}$ duchu tak ekspansywnej dziś retromody narracją historyczną.

\section{Reportażowa saga rodzinna: ustalenia genologiczne}

Jak zauważa Anna Zatora, na gruncie badań genologicznych pojęcie kroniki rodzinnej nie doczekało się jeszcze precyzyjnego omówienia i przez rozmaitych badaczy definiowane było w sposób raczej nieprecyzyjny. Badaczka zwraca uwagę przede wszystkim na problemy z nomenklaturą i zamienne stosowanie - obok określeń typu „saga rodzinna” czy „kronika rodzinna” - pojęć takich jak „powieść rodzinna” czy „powieść pokoleniowa”.

Konwencje omawianego tu gatunku są wyjątkowo złożone. Obok sag rodowych, przedstawiających w wyczerpujący i tworzony z epickim rozmachem sposób historyczne dzieje danej rodziny, wskazać należy także sagi współczesne, ogniskujące się wokół wydarzeń współczesnych danemu autorowi ${ }^{5}$. Cechą jednych i drugich jest wielowątkowość, realizm, obszerność i tematyczne zogniskowanie wokół opisywanych z dużą drobiazgowością losów bliższych i dalszych krewnych. Jak wskazuje Lori Ween, elementem spajającym tak zróżnicowane realizacje gatunkowe jest uwypuklony w toku narracji motyw utraty. Status sagi rodzinnej zyskują bowiem często opowieści o historii znikania określonej mikrospołeczności, wraz z odejściem której dochodzi do zachwiania dawnego

4 Por. A. Zatora, Saga rodzinna - próba uporządkowania i konceptualizacji gatunku, „Zagadnienia Rodzajów Literackich" 2017, z. 2, s. 29-30.

5 Por. Tamże, s. 32. 
porządku świata. Nikną bowiem bezpowrotnie także ważne dla niej wartości, zasady, tradycje czy normy $y^{6}$.

Christine Bridgwood stawia hipotezę, że saga rodzinna pod względem fabularnym wyraźnie odróżnia się od popularnych powieści fikcjonalnych: „The saga differs from other popular fiction genres in its lack of drive towards narrative closure and its tendency to begin at the point where romance stops"7. Jej fabuła (podobnie jak dzieje się to w gatunkach non-fiction) nie musi być tak rygorystycznie podporządkowana tworzeniu zaskakujących rozwiązań narracyjnych, których miejsce zajmować może chociażby żywioł dygresyjny.

W swym literackim wydaniu sagi rodzinne zbliżają się pod wieloma względami do powieści-rzeki, którą wyróżnia skrupulatna charakterystyka postaci, mocne uprzywilejowanie problematyki codzienności, mimetyzm oraz istotna rola, jaką w toku narracji odgrywa czas ${ }^{8}$. Tak ujmowana saga rodzinna kojarzona jest przede wszystkim z formą fikcjonalną, o czym świadczą najpopularniejsze realizacje gatunkowe, by przywołać tylko Noce i dnie Marii Dąbrowskiej, Sagę rodu Forsyteów Johna Galsworthy’ego czy Buddenbrooków Thomasa Manna.

Co istotne, na gruncie twórczości non-fiction także zauważyć można niezwykle ciekawe realizacje, skoncentrowane wokół autentycznych losów rodzinnych ukazanych na tle precyzyjnie sportretowanej epoki. W ich zrekonstruowaniu istotne stają się nie tylko dokumenty, ale także historia mówiona, które wspólnie stanowią o autentyzmie opisywanych wydarzeń, miejsc czy bohaterów. Wspomnieć należy przede wszystkim reportaż Dzieje rodziny Korzeniewskich Melchiora Wańkowicza, dokumentujący życie polskich uchodźców wojennych, którzy we wrześniu 1939 roku dotarli do Lwowa99. Obok tekstów opartych na narracji biograficznej (książka Wańkowicza bazuje na relacjach Oli Korzeniewskiej) historie rodzinne wplecione zostają często w ramy autoreportażu ${ }^{10}$, by przywołać wspomniane już prace Sznajderman i Zaremby Bielawskiego, tom Topografia pamięci Martina Pollacka czy obszerne autobiograficzne fragmenty Wyspy Węży Małgorzaty Szejnert.

O niefikcjonalnej odmianie sagi rodzinnej wspomina w swych ustaleniach genologicznych Zatora. Definiując sagę jako „obszerny utwór narracyjny opisujący dzieje rodziny przez kilka pokoleń na tle przeobrażeń społeczno-kulturowych”ı1,

6 Por. L. Ween, Family Sagas of the Americas: «Los Sangurimas» and "A Thousand Acres», „The Comparatist" 1996, vol. 20, s. 111-125.

7 Ch. Bridgwood, Family Romances: The Contemporary Popular Family Saga, w: The Progress of Romance. The Politics of Popular Fiction, red. J. Radford, London 1986, s. 167.

8 Por. A. Zatora, Saga rodzinna..., s. 29-30.

9 Por. A. Malcer-Zakrzacka, Melchiora Wańkowicza dwa odmienne spojrzenia na Rosję, „Jednak Książki” 2006, nr 5, s. 67-86.

10 Por. E. Żyrek-Horodyska, Reportaż biograficzny czy biografia reportażowa? Refleksje genologiczne i analiza przypadku, „Autobiografia” 2018, nr 2, s. 173.

11 A. Zatora, Saga rodzinna..., s. 36. 
badaczka zaznacza, że występuje ona w dwóch odmianach: powieściowej oraz dokumentalnej, zawierającej w sobie fragmenty o charakterze autobiograficznym i biograficznym. Tylko dla porządku wspomnieć warto także o trzeciej - niejako pogranicznej i silnie współgrającej z duchem ponowoczesności - hybrydycznej, sylleptycznej odmianie, określanej za Małgorzatą Madecką jako „apokryf rodzinny". Ta zbeletryzowana kronika rodzinna jest sui generis grą z kronikarskim paradygmatem autentyzmu, łączy bowiem narrację autobiograficzną $\mathrm{z}$ elementami fikcji ${ }^{12}$.

Saga reportażowa jest szczególną odmianą sagi dokumentarnej, realizującą funkcje przypisane tradycyjne przekazom dziennikarskim i przygotowaną zgodnie z reportażową poetyką. W tym gatunku typowa dla literatury funkcja rozrywkowa zostaje niejako zepchnięta na drugi plan, ustępując miejsca funkcji informacyjnej, realizowanej poprzez osadzenie prywatnych historii w szerokim tle społeczno-politycznych wydarzeń. Tworzona przez autora-popularyzatora narracja historyczna podporządkowana zostaje panoramicznemu i rozłożonemu w czasie portretowaniu losów danej rodziny. Jako taka opiera się zatem na faktografii i wyraźnie dąży do asertoryczności. W odróżnieniu od przekazów stricte historycznych prezentowana jest jednak z właściwej reportażowi subiektywnej perspektywy, wykreowanej przez autora pełniącego funkcję uczestnika, świadka, słuchacza bądź rekonstruktora zdarzeń ${ }^{13}$.

Reportażowe sagi rodzinne z powodzeniem absorbują elementy charakterystyczne zarówno dla gatunków literackich, jak i form dziennikarskich. W przekazach tego typu często dochodzi do fuzji poetyki eseju, powieści, reportażu, wywiadu i (auto)biografii. O ile ukształtowanie narracyjne tekstu (jak również książkowy sposób jego dystrybucji) przypomina raczej formę powieściową, o tyle warstwa włączonych w tekst licznych autokomentarzy i osobistych refleksji sugestywnie zbliża $\mathrm{z}$ kolei omawiany tu gatunek do prasowej publicystyki. $\mathrm{W}$ przypadku sagi reportażowej ważną rolę odgrywają także dołączone do tomu fotografie i dokumenty, które w narracjach powieściowych nie pełnią raczej istotniejszej funkcji. W formach non-fiction stanowią natomiast potwierdzenie dokumentarności przekazu, są elementem przyjmowanej przez autora strategii unaoczniającej i (pozornym, choć ciągle jeszcze trudnym do zastąpienia przez inne medium) gwarantem autentyzmu przekazu.

Niewątpliwie reportażowe sagi rodzinne - chociażby ze względu na ich obszerność, szczegółowość i autobiografizację dyskursu - sytuują się obecnie na pograniczach genologii dziennikarskiej. O tym, że krytycy i badacze dostrzegają nie tylko ich walory literackie, ale także dziennikarski potencjał, świadczy nie-

${ }_{12}$ M. Medecka, Apokryf rodzinny jako odmiana dwudziestowiecznej powieści historycznej, Lublin 2007.

13 Por. K. Wolny-Zmorzyński, Reportaż - jak go napisać? Poradnik dla słuchaczy studiów dziennikarskich, Warszawa 2004, s. 50-62. 
wątpliwie przyznanie Zarembie Bielawskiemu tytułu laureata dziesiątej edycji nagrody im. Ryszarda Kapuścińskiego za najlepszy reportaż. Książka Sznajderman nominowana była do tej nagrody w ósmej edycji konkursu.

\section{(Auto)portret reportera-archiwisty}

Saga reportażowa nosi wyraźne znamiona autoreportażu, o którym dziennikarz Mariusz Szczygieł pisał swego czasu w następujący sposób: „Potraktować siebie jak bohatera reportażu, a ze swojego intymnego życia stworzyć fabułę non-fiction - to duża odwaga"14. Konstrukcyjną ramą dla rodzinnej opowieści stają się nierzadko losy samego autora tomu. Jako dociekliwy rekonstruktor funkcjonuje on jednocześnie w dwóch przestrzeniach: określonym hic et nunc oraz rzeczywistości historycznej, w której zakorzenione są wspomnienia i rodzinne opowieści. Takie (de facto raczej nietypowe dla gatunków dziennikarskich) usytuowanie figury autora (jednocześnie jako narratora i bohatera opowieści) nie pozostaje bez wpływu wartość informacyjną przekazu. Zależność tę zasygnalizował swego czasu Philippe Lejeune, pisząc: „[...] w autobiografii ścisłość nie jest kwestią najważniejszą. W autobiografii jest bowiem niezbędne, by pakt referencjalny został zawarty i dotrzymany, lecz rezultat nie wymaga oceny w kategoriach ścisłego podobieństwa. W świetle czytelniczych kryteriów pakt ten może być dotrzymany niedobrze i nie przekreśla to referencjalnej wartości autobiografii [...], jak to ma miejsce w przypadku tekstów historycznych i dziennikarskich"15. Reportażowa saga rodzinna, tak intensywnie markowana autorską sygnaturą, $\mathrm{z}$ jednej strony dąży do dokumentarnej transparencji, z drugiej - jako jedno z ważniejszych źródeł informacji traktuje indywidualną pamięć i wspomnienia piszącego, niepoddające się głębszej obiektywizacji.

Eksplorowanie przez dziennikarza przeszłości jest próbą dotarcia do tej grupy czytelników, którzy nad obszerne powieści (bezpowrotnie tracące już przyznany im przez Stendhala status „Zwierciadła przechadzającego się po gościńcu”) preferują narracje oparte na rzeczywistych wydarzeniach, odkrywające prawidła obowiązujące $\mathrm{w}$ świecie realnym, a nie w przestrzeni powołanej do istnienia li tylko siłą wyobraźni autora. Zainteresowanie gatunkiem opierającym się na drobiazgowej rekonstrukcji i wnikliwej dziennikarskiej archiwistyce jest - by posłużyć się określeniem Mariana Golki - swoistym przejawem „głodu autentyzmu”'16, wyrażającego się pragnieniem obcowania $\mathrm{z}$ „prawdziwymi”

14 Słowa te zanotował Szczygieł na okładce książki Roberta Rienta pt. Świadek (Warszawa 2015); por. https://dowody.com/ksiazka/robert-rient-swiadek/ [dostęp: 6.01.2020].

15 P. Lejeune, Wariacje na temat pewnego paktu. O autobiografii, tłum. W. Grajewski i in., Kraków 2001, s. 47-48.

16 M. Golka, Głód autentyzmu, „Opuscula Sociologica” 2016, nr 1, s. 5-13. 
bohaterami, „rzeczywistymi historiami”, „realnym” życiem i śmiercią. Trafnie prawidłowość tę uchwycił Rafał Szczerbakiewicz, którego zdaniem: „[...] w konkretnym przypadku reportażu opartego na archiwum obiektywnie podwyższa się faktor "prawdziwości» opowieści w stosunku do typowych praktyk kultury popularnej. To, co dotychczas mieściło się w granicach prawdopodobieństwa, teraz otrzymało sankcję dokumentalną. Możemy śledzić zawikłane dzieje konkretnych zbrodni i losy ludzi w nie uwikłanych zrekonstruowane dzięki żmudnej pracy archiwistycznej"17. W przypadku tego typu publikacji niejako w nawias wzięte zostają postulaty dziennikarskiej naoczności i aktualności. Ich miejsce zajmuje przypominająca pracę detektywa wyprawa po śladach, skupiona raczej na zagadnieniach ważnych, ponadczasowych, uniwersalnych aniżeli doraźnych tematach, które równie szybko jak pojawiają się w agendzie mediów - znikają z niej.

$\mathrm{W}$ pracy dziennikarza-archiwisty rzeczą o fundamentalnym znaczeniu staje się jawność warsztatu, przejawiająca się w skrupulatnym informowaniu czytelnika o poszczególnych podejmowanych krokach, gromadzonych źródłach informacji, procesie docierania do nich oraz krytycznej ich analizie. Wiedzę na temat przeszłości piszący czerpie najczęściej z prywatnych bądź publicznych archiwów, z oficjalnych dokumentów, fotografii, korespondencji, pamiętników, biografii, drobnych zapisków. Dostęp do przeszłości staje się możliwy także za sprawą przedmiotów, uruchamiających pracę pamięci i stanowiących swego rodzaju łącznik pomiędzy czasem, w którym żyli bohaterowie, a momentem dokumentowania ich losów. Współcześnie - co warto podkreślić - ten typ reportażowych narracji zyskuje wśród dziennikarzy coraz większe zainteresowanie, czego dowodem są takie tomy, jak Wyspa klucz Szejnert, Koronkowa robota. Sprawa Gorgonowej Cezarego Łazarewicza czy Marlene Angeliki Kuźniak.

W procesie tworzenia reportażowej sagi rodzinnej dla dziennikarza-archiwisty równie istotną rolę jak źródła zastane odgrywa pamięć autobiograficzna, będąca - jak pisze Maria Czempka-Wewióra - „specyficznym typem pamięci dotyczącym historii indywidualnej danej osoby i archiwizującym wspomnienia mające dla pamiętającego wartość emocjonalną"18. Jej zasada działania opiera się na integrowaniu ze sobą często fragmentarycznych, niekoherentnych narracji i przekształcaniu poszczególnych wspomnień w dokumentarną narrację, „co nieraz odbywa się za cenę uproszczeń i zniekształcen'”'19.

17 R. Szczerbakiewicz, Archiwistyczny reportaż kryminalny. Retrokryminalna paraliteratura, „Annales Universitatis Mariae Curie-Skłodowska” 2018, nr 2, s. 65.

${ }_{18}$ M. Czempka-Wiewióra, «Pisane z pamięci». Strategie narracyjne we współczesnej literaturze autobiograficznej, „Acta Universitatis Lodziensis. Folia Litteraria Polonica” 2011, nr 2, s. 192.

19 Tamże. 


\section{Dom z dwiema wieżami M. Zaremby Bielawskiego}

Książka Zaremby Bielawskiego wyrasta z silnego przywiązania reportera do „archiwistycznego" dziennikarstwa, czego dowód dał autor już w swej bodaj najgłośniejszej książce reportażowej pt. Higieniści. Z dziejów eugeniki. W niej również - podobnie jak w Domu... - bardzo wyraźnie uobecnione zostały wątki biograficzne związane z działalnością ojca reportera, Oskara Bielawskiego. Dziennikarz, wielokrotnie podkreślając wagę i znaczenie faktograficznej, odpersonalizowanej narracji, zaryzykował hipotezę, że w przypadku reportażu literackiego może okazać się ona niewystarczająca: „Moje reportaże są bardziej publicystyczne, strukturalne. Ale czasami trzeba, moim zdaniem, wejść w publicystykę w tekście reporterskim. Jeżeli spiętrzę cały szereg faktów, które się kłócą ze sobą, to wiem, że w głowie czytelnika powstaje znak zapytania: «Co on chce przez to powiedzieć?». I wtedy wypada zmienić ton i wtrącić: «Ja mam taką hipotezę, zobaczymy, czy ona się sprawdzi», przemówić własnym głosem"20. Dom $z$ dwiema wieżami jest udaną próbą zrealizowania nakreślonych przez dziennikarza postulatów. Zaremba Bielawski przeprowadza czytelnika przez skomplikowaną historię swej polsko-żydowskiej rodziny, portretując jej widmowe losy na tle wydarzeń przełomowych dla polskiej historii XX wieku. Znamienne, że o historii tej reporter pisze z wyraźnego kulturowego dystansu, jako nastolatek wyjechał bowiem do Szwecji. Obecnie jako dziennikarz sztokholmskiego „Dagens Nyheter” swe teksty publikuje w języku szwedzkim, stąd określany jest mianem „szwedzkiego dziennikarza polskiego pochodzenia”21. $\mathrm{Z}$ tego chociażby względu jego perspektywa różni się od ujęcia Sznajderman; konotuje dystans i zgoła odmienne podejście do kategorii takich jak zadomowienie czy zakorzenienie.

Julia Fiedorczuk, jurorka X edycji nagrody im. Ryszarda Kapuścińskiego, określiła tom Zaremby Bielawskiego jako „nowy rodzaj osobistego reportażu”"22. Książka ta powstała z połączenia technik reporterskich z pasją dociekliwego archiwisty oraz wnikliwą introspekcją charakterystyczną dla pisarstwa autobiograficznego. Należy podkreślić, że autor bardzo wyraźnie ujawnia w niej przed czytelnikiem kulisy swojego warsztatu, demaskuje proces powstawania reportażu, wskazuje luki w pamięci, zapewniając przy tym o referencjalnym charakterze tekstu. „Wszystko w tej książce jest prawdziwe, ale w nic nie trzeba

20 A. Wójcińska, Perspektywa mrówki. Rozmowy z reporterami świata, Wołowiec 2015, s. 21.

21 Por. K. Frukacz, Szwedzki Polak - Polski Szwed. Maciej Zaremba Bielawski wobec polskości i polskiej szkoły reportażu, w: Literatura polska $w$ świecie. T. VII Reportaż $w$ świecie, światowość reportażu, red. K. Frukacz, Katowice 2019, s. 96.

22 O książce «Dom z dwiema wieżami» («Huset med de två torlen») Macieja Zaremby Bielawskiego w przekładzie Mariusza Kalinowskiego pisze jurorka Julia Fiedorczuk, na: http://www.kulturalna. warszawa.pl/kapuscinski,6,11027.html [dostęp: 6.01.2020]. 
wierzyć"23 - podkreśla reporter, wielokrotnie dekonstruujący wartość informacyjną poszczególnych fragmentów historii. „Tu istnieją trzy wersje”24, „Tak chcę myśleć" ${ }^{25}$, „Ja chyba wiem, co się zdarzyło" 26 , „Tak to musiało byc”"27 - to tylko nieliczne spośród zawartych w tomie autotematycznych sformułowań, które podają w wątpliwość faktograficzność reporterskich ustaleń. Kwestionują także uniwersalizm historycznego dyskursu, pokazując, że historia rodzinna, dzieje krewnych, społeczności i narodów, są przede wszystkim opowieścią, która wytwarza się i konstytuuje w samym procesie mówienia. Jako taka agreguje mikrohistorie pochodzące $\mathrm{z}$ często niekoherentnych, niepełnych, a nawet wzajemnie wykluczających się źródeł. Mamy tu zatem do czynienia ze zjawiskiem, które Małgorzata Medecka określiła mianem faktograficznej niekompetencji twórcy ${ }^{28}$. By ją zniwelować, piszący owe szczeliny w pamięci wypełnia sugestiami, domysłami, wyobrażeniami, przy czym jednocześnie z dziennikarską rzetelnością informuje czytelnika o tych fragmentach kroniki rodzinnej, które zostały zrekonstruowane właśnie w ten sposób.

Tytułowe dwie wieże stają się filarami opisywanego przez Zarembę Bielawskiego domu. Żydowscy przodkowie matki reportera (Lili) i szlacheccy krewni jego ojca (Oskara) zostają w procesie pisania niejako na nowo powołani do istnienia i włączeni w pozorny dialog z autorem tekstu. Zabieg ten, wskrzeszający widma rzeczywistości, pozwala zniwelować dystans pomiędzy przeszłością a współczesnością, wprowadzając przy tym do narracji historycznej niezwykle osobisty, a momentami wręcz intymny ton. Warto przywołać kilka charakterystycznych fragmentów, zdecydowanie wykraczających w swej poetyce poza precyzyjny, dokumentarny reportażowy dyskurs: „O, tato... Nie oczekujesz, że te słowa dotrą za twojego życia. Masz tylko nadzieję, że zostaną przechowane. Pamiętasz, jak opowiedziałeś mi o Ananke?”29; „Ach, droga nianiu, której imienia nie pamiętam, moja pierwsza damo”30; „Tato kochany. Ile odwagi i ufności z twojej strony, kiedy ucinasz tym "chyba rozumiesz»" ${ }^{1}$. Przywołane cytaty są świadectwem wysoce nostalgicznego tonu, każącego sytuować książkę Zaremby Bielawskiego w obszarze form autoreportażowych. W omawianym tu tomie, stanowiącym nowe wcielenie reportażu, zdecydowanie dominuje postawa autobiograficzna, wyrażająca się poprzez narrację pierwszoosobową, intencjonalnie uwypuklającą

\footnotetext{
23 M. Zaremba Bielawski, Dom..., s. 15.

24 Tamże, s. 217.

25 Tamże, s. 283.

26 Tamże, s. 268.

27 Tamże, s. 269.

28 Por. M. Medecka, Apokryf rodzinny..., s. 63.

29 M. Zaremba Bielawski, Dom..., s. 280.

30 Tamże, s. 30.

31 Tamże, s. 105.
} 
rolę narratora-bohatera jako osoby będącej spadkobiercą rodzinnej historii, swoistym depozytariuszem wspomnień i głosem tych, którym zostało odebrane prawo do mówienia. Autor w ten sposób swą rolę definiuje już w otwierającym książkę rozdziale, oświadczając: „Teraz wiem o nich więcej, niż oni wiedzieli o sobie nawzajem. Tę historię opowiadam dla nich"32.

W konstruowanej opowieści Zaremba Bielawski skrupulatnie wymienia najistotniejsze źródła informacji, wśród których dominującą rolę odgrywa indywidualna oraz wspólnotowa pamięć, osobiste refleksje, archiwalne dokumenty, fotografie, teksty publikowane $\mathrm{w}$ dawnej prasie. Piszący $\mathrm{z}$ reporterską precyzją przygląda się poszczególnym nośnikom, zwracając przy tym uwagę nie tylko na ich treść, ale także na indeksującą określone momenty historyczne formę przekazu. Przykładowo, portretując nieżyjących już członków własnej rodziny, reporter wnikliwie analizuje utrwalone w materialnym nośniku ślady ich obecności: „Te słowa są napisane drobniejszym stylem niż ciąg dalszy. Za to wykrzyknik jest postawiony z całą mocą. Wygląda prawie jakby chciał ulecieć z kartki. Moment musiał być uroczysty i zarazem podszyty niepewnością. Oto on, Izaak, pierwszy ze swego rodu ferował wyrok w imieniu państwa"33. $\mathrm{W}$ kronice rodzinnej Zaremby Bielawskiego czytelnik z łatwością dostrzec może tego rodzaju rozmaite autotematyczne „szwy”, spajające opowieść o losach poszczególnych postaci. Dowodzą one niezwykle szerokich kompetencji narratora, który dokładnie ujawnia, jak wyglądał proces gromadzenia informacji, a nawet jakie wywoływał w nim emocje. Tak budowana opowieść opiera się na świadomym i precyzyjnym stopniowaniu napięcia, zbliżającym narrację reportażową do powieściowej: „Ostatnie archiwum. Pociągam za brudny sznurek. Supełek rozwiązuje się z pyknięciem, które zostawia w powietrzu chmurkę pyłu. Teczka otwarta. Pokój znika, wspomnienie marzenia z dzieciństwa nachodzi mnie z taką siłą, że zapominam, gdzie jestem. Piasek, pustynia, odsuwam ciężki kamień i czuję powiew powietrza. Wdycham je i już wiem, ze dotarłem na miejsce. Znalazłem grób faraona" 34 . W przytoczonym tu fragmencie - podobnie jak w wielu innych rozdziałach tomu - istotną rolę odgrywa praesens historicum, pozwalający znacząco zniwelować dystans pomiędzy przeszłością a teraźniejszością i włączyć rodzinne dzieje w aktualny kontekst. Dzięki wielokrotnie stosowanym strategiom unaoczniającym uwaga czytelnika skupiona jest (wzorem powieści sensacyjnej) nie tylko na wydarzeniach historycznych, ale także dokumentowanej skrupulatnie dziennikarskiej „archiwistyce”, a zatem metatekstowych komentarzach odnoszących się do samego procesu zdobywania informacji, ich selekcjonowania i interpretacji.

\footnotetext{
32 Tamże, s. 11.

33 Tamże, s. 130.

34 Tamże, s. 163.
} 
Znamienne, że reporter nie ukrywa swego zaangażowania i chętnie dzieli się z odbiorcą towarzyszącymi mu emocjami, traktując sam fakt zapisywania rodzinnej historii jako proces dynamiczny, rozgrywający się niejako przed oczyma czytelnika. Tak opowiadana przeszłość nie jawi się wcale jako zamknięta i podsumowana, lecz wchodzi w interakcje z teraźniejszością: „Czuję, że muszę porzucić los dziadka. Widzę, co już zdążył zrobić z moją twarzą. To brzydkie skrzywienie warg, jak u mamy, kiedy mówiła «łajdaka». I na tym bym skończył, gdyby nie pewien poster. Pojawia się niespodziewanie, gdy szukam czegoś innego" ${ }^{35}$. Trudno zabieg ten określić li tylko sprawnym chwytem retorycznym, mającym na celu przejście pomiędzy kolejnymi tematami. Wyraźnie uwypukla on natomiast sam proces pracy nad tekstem i silnie eksponuje kreacyjną rolę narratora jako sui generis "twórcy” powoływanego niejako na nowo do istnienia utraconego świata.

Dokumentarna opowieść o losach rodziny autora posiada wiele cech typowych dla dyskursu reportażowego. Cechuje ją rzeczowa faktografia, asertoryczność sądów, czerpanie przez piszącego z licznych źródeł zastanych, aktualność podejmowanej problematyki (relacje polsko-żydowskie, tematyka społecznego wykluczenia). Jednocześnie jednak w konstruowanym przez Zarembę Bielawskiego dyskursie odnaleźć można wiele fraz presuponujących hipotetyczny charakter formułowanych sądów, a nawet felietonistyczne oparcie się na sugestiach, przeczuciach, domysłach. „Tak to musiało być"36, „Ja chyba wiem, co się zdarzyło” ${ }^{\prime 3}$, „[...] nie wiem, jakimi słowami Oskar sprzeciwia się przełożonemu. Zgaduję jednak, że ma już dość obłudy"38 - to tylko nieliczne z bardzo wielu utrzymanych w podobnym tonie wypowiedzi, rozsadzających faktograficzność narracji i ujawniających jej wyraźne ciążenie w stronę pamiętnika czy eseistyki.

\section{Fałszerze pieprzu M. Sznajderman}

Tom Fałszerze pieprzu, zarówno pod względem podejmowanych zagadnień, jak również wyraźnego usytuowania ich w kontekście refleksji nad indywidualną oraz wspólnotową pamięcią, ściśle koresponduje z głównymi wątkami omawianymi w książce Zaremby Bielawskiego. Podobnie jak w Domu... losy polskich i żydowskich przodków Sznajderman ukazane zostają jako rozwijające się paralelnie, ale osobno; jako wspólistniejące, lecz pozostające wręcz w całkowitej od siebie izolacji. Autorka, poszukując ich punktów wspólnych i dążąc do potwierdzenia autentyzmu opowieści, rekonstruuje - jak zaznacza w podtytule

\footnotetext{
35 Tamże, s. 157.

36 Tamże, s. 269.

37 Tamże, s. 268.

38 Tamże, s. 244.
} 
książki - „historię rodzinną”, usytuowaną na szerokim tle społecznych i politycznych wydarzeń XX wieku.

We wstępie do Fałszerzy... Martin Pollack zwrócił uwagę, że genologiczne sklasyfikowanie książki wymyka się tradycyjnym ramom poetologicznym, gdyż $\mathrm{w}$ tego rodzaju publikacjach wyróżniają się przede wszystkim pograniczne wpływy gatunkowe: „Literacka interpretacja rodzinnych historii to pole, na którym rozwijają się różne gatunki: od form beletrystycznych i dokumentalnych po hybrydy wyrosłe gdzieś pomiędzy, których nie da się precyzyjnie przyporządkować do tej lub innej kategorii" ${ }^{39}$. W tomie Sznajderman bardzo wyraźnie subiektywne wątki autobiograficzne splatają się z obiektywizującą reportażową i historyczną narracją, osobiste wspomnienia stają się kontekstem dla analizowanych dokumentów, a erudycyjna opowieść przeplata się z intymnymi wspomnieniami. Książka doskonale wpisuje się w poetykę opisanych przez Clifforda Geertza "gatunków zmąconych" ${ }^{40}$. Założenie to wybrzmiewa $\mathrm{z}$ wypowiedzi Natalii Żórawskiej-Janik, starającej się dookreślić genologiczny charakter Fałsze$r z y . . .$. „Publikacja jest [...] połączeniem rodzinnej sagi z elementami reportażu i kroniki, którą wypełniają przede wszystkim historie o losach ojca i przodków, daty, fakty, historyczne informacje. Za tym kronikarskim charakterem kryją się emocje i wzruszenie pisarki rzadko wyjawiającej uczucia, skupiającej się na historii dotyczącej krewnych"41. Sznajderman z kolei, starając się wytyczyć teoretyczne ramy publikacji, włącza swój tom w nurt narracji pamięciowych, akcentując przede wszystkim jego silne autobiograficzne usytuowanie: „Wbrew tytułowi to nie jest książka historyczna. To książka o pamięci. A właściwie o dwóch pamięciach, które się w żadnym miejscu nie spotykają. I o losach, które od stuleci toczyły się równolegle, nigdy razem. Losach moich dwóch rodzin - polskiej i żydowskiej" ${ }^{42}$. Ów osobisty, momentami wręcz intymny ton stosowany przez piszącą przywodzi na myśl figurę czułego narratora, któremu swój noblowski wykład poświęciła Olga Tokarczuk. „Czułość personalizuje to wszystko, do czego się odnosi, pozwala dać temu głos, dać przestrzeń i czas do zaistnienia, i ekspresji”" ${ }^{43}$ - mówiła Tokarczuk, a fraza ta zdaje się doskonale charakteryzować przyjmowaną przez autorkę Fałszerzy... perspektywę narracyjną. W toku opowieści pisząca niejako na nowo powołuje do istnienia utracony świat, wydobywa z niebytu i niepamięci miejsca, postaci i wydarzenia,

39 M. Pollack, Mowa jednak złotem, w: M. Sznajderman, Fałszerze..., s. 9.

40 Por. C. Geertz, O gatunkach zmąconych. Nowe konfiguracje myśli społecznej, „Teksty Drugie” 1990, nr 2, s. 113-130.

${ }^{41}$ N. Żórawska-Janik, Nieustająca praca pamięci. «Fałszerze pieprzu» Moniki Sznajderman, "Autobiografia” 2018, nr 2, s. 155.

42 M. Sznajderman, Fałszerze..., (informacja pochodzi z tylnej okładki tomu).

43 «Czuły narrator». Pelny tekst noblowskiego wykładu Olgi Tokarczuk, na:

https://www.rp.pl/Literatura/191209471-Czuly-narrator-Pelny-tekst-noblowskiego-wykladu-Olgi-Tokarczuk.html [dostęp: 6.01.2020] 
swą uwagę zatrzymując na detalach, drobiazgach, które zazwyczaj wykraczają poza obszar dokumentarnej narracji historycznej.

Zasadnicza różnica pomiędzy opowieścią rodziną tworzoną przez Zarembę Bielawskiego a tekstem Sznajderman odnosi się do sposobu sfunkcjonalizowania dołączonych do tomu fotografii. O ile w przypadku pierwszego autora zdecydowanie ustępują one miejsca pisanej narracji i pojawiają się w tomie stosunkowo rzadko, o tyle w Fałszerzach... uderza współobecność obu form. Stanowią one immanentny składnik kroniki rodzinnej, a nawet punkt wyjścia do zajęcia się przez autorkę tematem rodzinnych dziejów. Historia o losach krewnych powróciła bowiem do Szjanderman wraz z przysłanymi ze Stanów Zjednoczonych fotografiami, dokumentującymi przedwojenne losy jej bliskich i posiadającymi paradoksalną moc ocalenia istnień: „Przetrwali tylko na tych fotografiach. Fotografiach cudem ocalonych, pieczołowicie przechowywanych i przysłanych ci z Ameryki ledwie kilka lat temu. [...] Opowieść o losie tych zdjęć, które przetrwały Zagładę za oceanem [...] to symboliczna opowieść o życiu w świecie przedholokaustowym"44. Podążając śladami takich teoretyków fotografii, jak Roland Barthes czy Susan Sontag, Sznajderman bardzo ściśle wiąże fotografię ze śmiercią. Warto $\mathrm{w}$ tym kontekście przywołać jedną $\mathrm{z}$ wypowiedzi Sontag, która wyraźnie koresponduje z uwagami autorki Fałszerzy..., pokazując, że fotografia funkcjonuje współcześnie jako swoiste memento mori: „Robiąc zdjęcie - pisała Sontag - stykamy się ze śmiertelnością, kruchością, przemijalnością innej osoby lub rzeczy. Właśnie dlatego, że wybieramy jakąś chwilę, wykrywamy ją i zamrażamy, wszystkie zdjęcia stanowią świadectwo nieubłagalnego przemijania" ${ }^{\prime 5}$. Z drugiej jednak strony - co Sznajderman akcentuje jeszcze dobitniej - fotografia jest narzędziem realizmu, świadectwem, źródłem informacji, swoistym dowodem w sprawie. Tę właśnie funkcję zdjęć wyczytuje pisząca z prac Amerykanki, parafrazując jej ustalenia następującymi słowy: „Fotografia, znowu mówi Susan Sontag, dostarcza mi dowodów rzeczowych, pozwalających wierzyć, że istnieli" ${ }^{\prime \prime}$. W książce Sznajderman temat fotografii nie wiąże się z prostą ilustracyjnością, lecz osadzony zostaje bardzo wyraźnie w refleksji na temat pamięci i śladu. Pisząca akcentuje ocalającą moc fotografii - traktuje ją jako narzędzie umożliwiające przynajmniej pozorny dostęp do bezpowrotnie utraconego już świata międzywojennego Miedzeszyna, w którym stał niegdyś zachowany już tylko na zdjęciach dom rodzinny jej przodków.

Intencją piszącej - prócz ocalenia historii rodziny - staje się otoczenie troską swoistych nie-miejsc pamięci ${ }^{47}$, topografii intencjonalnie zapominanych

${ }_{44}$ M. Sznajderman, Fałszerze..., s. 26.

45 S. Sontag, O fotografii, tłum. S. Magala, Kraków 2009, s. 23.

46 M. Sznajderman, Fałszerze..., s. 52.

47 Por. R. Sendyka, Pryzma - zrozumieć nie-miejsca pamięci (non-lieux de mémoire), „Teksty Drugie" 2013, nr 1-2, s. 323-344. 
i funkcjonujących już jedynie na przedwojennych fotografiach. To przestrzenie, w których niegdyś koncentrowało się życie krewnych autorki, a dziś „straciły pamięćc" ${ }^{\prime \prime}$, nie kotwiczą wspomnień okolicznych mieszkańców, zostały wymazane ze zbiorowej pamięci. Miejsce, gdzie stała przedwojenna willa Sznajdermanów, obecnie jest „kawałem ziemi między podwarszawskim willami” ${ }^{49}$. Reportażowa saga rodzinna rozpoczyna się eseistyczną refleksją nad statusem tego rodzaju miejsc: „Czym są miejsca, które straciły pamięć? Które ludzka pamięć omija, których przestaje dotykać? I co to za pamięć marnotrawna, która buja w obłokach, zamiast opowiadać, przywoływać historie? Miejsca, których pamięć nie otacza troską, umierają. Dziwaczeją i dziczeją, porośnięte zielskiem zapomnienia. Jak ten opuszczony kawałek ziemi pomiędzy domami w podwarszawskim Miedzeszynie" ${ }^{30}$. W opowieści rodzinnej dom (określona geografia, przestrzeń, budynek) stanowi centrum opisywanego mikroświata. W pracy Sznajderman urasta on do rangi symbolu utraconej pamięci, której unicestwienie nastąpiło wraz ze zniknięciem materialnej konstrukcji.

Analizując warstwę narracyjną Fałszerzy ..., dostrzec możemy pewną istotną zbieżność z pracą Zaremby Bielawskiego. Podobnie jak twórca Domu... Sznajderman także wprowadza do reportażu apostrofy skierowane do swojego ojca, włączając go tym samym w iluzoryczny dialog. Liczne fragmenty tomu, pisane $\mathrm{z}$ reportażową skrupulatnością, przeplatane zostają passusami sprawiającymi wrażenie niezwykle intymnej rozmowy, której czytelnik staje się mimowolnym świadkiem: „Ocalałeś jako jedyny z nich wszystkich. Nie mogłeś jednak udźwignąć pamięci. Uniosłeś ledwie okruchy, z których teraz ja próbuję zbudować opowieść. Zaludnić puste miejsce na miedzeszyńskiej polanie. Niedawno pojechałam tam po raz pierwszy. Zabudowę podwarszawskiej dzielnicy willowej przerywa las. Tam stoi twój pensjonat pamięci, tato"51. W innych fragmentach pisząca zwraca się do ojca: „Nie wiem, jak i którędy wracasz, wiem tylko, że pociągami przez Lipsk i Poznań, a bardzo chciałabym dokładnie poznać i zapamiętać tę drogę [...]” "52; „Próbuję sobie wyobrazić, jak idziesz, szesnastoletni, obok Abrama Wacera, niemal twojego rówieśnika z Warszawy, lub Jankiela Tugentmana, lat dwadzieścia, za Parysowa" ${ }^{53}$. Zacytowane wypowiedzi są próbą dookreślenia roli autorki, która, pełniąc funkcję rodzinnej archiwistki i rekonstruktorki zdarzeń, stawia sobie za cel przywrócenie pamięci o tym, co utracone. W geście konkretyzacji - by posłużyć się terminem Romana Ingardena - kronikarka i interpretatorka rodzinnych dziejów próbuje zapełnić „białe plamy”

\footnotetext{
48 M. Sznajderman, Fałszerze..., s. 19.

49 Tamże, s. 20.

50 Tamże, s. 19.

51 Tamże, s. 102.

52 Tamże, s. 150.

53 Tamże, s. 146.
} 
historii, ukonkretnić i zmaterializować w tekstowej formule wspomnienia oraz impresje. Imperatyw stałego konkretyzowania wspomnień wiąże się nie tylko z pragnieniem odtworzenia dziejów własnej rodziny, ale także pokazania szerszego historycznego tła, stanowiącego ważny appendix do opowieści o niezwykle skomplikowanej historii Polski w pierwszej połowie XX wieku.

„Pamięć zawsze znała tylko dwie formy legitymizacji: historyczną i literacką. Rozwijały się one równolegle, lecz dotąd zawsze oddzielnie. Dziś granica między nimi się zaciera" ${ }^{44}$ - pisał Pierre Nora. W swym tomie Sznajderman sprawnie łączy obie te optyki, wielokrotnie podkreślając przy tym, jak często przychodzi jej mierzyć się z problematyką niewyrażalnego. Narzuca ją i poniekąd ewokuje sam temat Zagłady oraz starająca się go opisać poetyka „ściśniętego gardła”. U jej podstaw stoi również brak bądź niekompletność źródeł, osobiste zaangażowanie w temat, ograniczenia reportażowej formy. Warto przywołać kilka spośród niezwykle licznych autotematycznych fragmentów Fałszerzy..., które w sposób szczególny uwypuklają miejsca domagające się autorskiej konkretyzacji: „Nie wiem, czy jestem w stanie w jakikolwiek sposób przywrócić im utracone istnienie [...]" "55; „Przywołuję te nazwiska, by dać odpocząć wyobraźni, rozpaczliwie poszukującej jakiegoś konkretu, jakiegoś punktu zaczepienia w straszliwej, abstrakcyjnej pustce”56; „Ciekawa jestem, jak układały się wasze stosunki z polskimi sąsiadami" ${ }^{57}$. Inkrustowanie tekstu tak licznymi autotematycznymi wypowiedziami, konotującymi wrażliwość opowiadającego i podkreślającymi autentyczność jego emocji, sprawia, że książka ta staje się de facto opowieścią o opowiadaniu, ujawniającą spajające poszczególne wątki odautorskie szwy i odkrywającą tym samym uniwersalizujący charakter każdej narracji historycznej.

\section{Podsumowanie}

Genologiczny transfer poetyk pomiędzy literacką sagą rodzinną a jej reportażowym odpowiednikiem jest jeszcze jednym argumentem potwierdzającym tezę o obserwowanej współcześnie karierze gatunków zmąconych oraz coraz bardziej wyrazistej interferencji form literackich i dziennikarskich. Znamienne, że proces ten dokonuje się w epoce szczególnego uprzywilejowania krótkich, lakonicznych form dziennikarskich. Reportażowa saga rodzinna, którą z jej literackim odpowiednikiem łączy realistyczne obrazowanie i przedstawienie losów rodzinnych na tle przełomowych wydarzeń historycznych, pod wieloma względami zdaje się odróżniać od dominującej w środkach

54 P. Nora, Między pamięcią a historią: lieux de mémoire, tłum. M. Borowski, M. Sugiera, „Didaskalia" 2011, nr 105, s. 27.

55 M. Sznajderman, Fałszerze..., s. 120.

56 Tamże, s. 147.

57 Tamże, s. 35. 
masowego przekazu retoryki. Odrzuca skrótowość na rzecz pogłębionej, obszernej narracji; w miejsce atrakcyjnych, szokujących, infotainmentowych przekazów wprowadza problematykę codzienności; podważa ów pozorny obiektywizm historycznych narracji i pokazuje reportera jako kogoś, kto nie tyle formułuje mocne tezy, ile stawia pytania, dzieli się wątpliwościami i odkrywa białe plamy w opowieści o przeszłości.

Omówione w niniejszym szkicu książki Zaremby Bielawskiego oraz Sznajderman wpisują się w nurt popularnych obecnie narracji autoreportażowych, zrywających z odpersonalizowanym, obiektywizującym tonem na rzecz opowieści silnie spersonalizowanych, eksponujących wrażliwość reporterskiego spojrzenia, jego zaangażowanie w temat, którego wyrazem jest wysoce intymistyczny styl wypowiedzi. Ważną składową obu książek jest jawność warsztatu oraz dokonywana przez obojga piszących krytyczna analiza źródeł zastanych i tzw. oral history. Elementy te skutecznie eksponują autentyzm dokumentowanych historii, pokazując jednocześnie, jak istotną rolę we współczesnym reportażu literackim odgrywają narracje pamięciowe i niesłusznie - jak się okazuje marginalizowana przez wiele redakcji prasowych dziennikarska archiwistyka.

\section{Bibliografia}

Bridgwood Ch., Family Romances: The Contemporary Popular Family Saga, w: The Progress of Romance. The Politics of Popular Fiction, red. J. Radford, London 1986.

Czempka-Wiewióra M., «Pisane z pamięci». Strategie narracyjne we współczesnej literaturze autobiograficznej, „Acta Universitatis Lodziensis. Folia Litteraria Polonica” 2011, nr 2.

«Czuły narrator». Pełny tekst noblowskiego wykładu Olgi Tokarczuk, na:

https://www.rp.pl/Literatura/191209471-Czuly-narrator-Pelny-tekst-noblowskiego-wykladu-Olgi-Tokarczuk.html [dostęp: 6.01.2020].

Frukacz K., Szwedzki Polak - Polski Szwed. Maciej Zaremba Bielawski wobec polskości i polskiej szkoły reportażu, w: Literatura polska w świecie. T. VII Reportaż w świecie, światowość reportażu, red. K. Frukacz, Katowice 2019.

Geertz C., O gatunkach zmąconych. Nowe konfiguracje myśli społecznej, „,Teksty Drugie”1990, nr 2. Golka M., Głód autentyzmu, ,Opuscula Sociologica” 2016, nr 1.

Lejeune P., Wariacje na temat pewnego paktu. O autobiografii, tłum. W. Grajewski i in., Kraków 2001. Malcer-Zakrzacka A., Melchiora Wańkowicza dwa odmienne spojrzenia na Rosję, "Jednak Książki” 2006, nr 5.

Medecka M., Apokryf rodzinny jako odmiana dwudziestowiecznej powieści historycznej, Lublin 2007. Nora P., Między pamięciq a historią: lieux de mémoire, tłum. M. Borowski, M. Sugiera, „Didaskalia” 2011, nr 105.

O książce «Dom z dwiema wieżami» («Huset med de två torlen») Macieja Zaremby Bielawskiego w przekładzie Mariusza Kalinowskiego pisze jurorka Julia Fiedorczuk, na: http://www.kulturalna. warszawa.pl/kapuscinski,6,11027.html [dostęp: 6.01.2020].

Sendyka R., Pryzma -zrozumieć nie-miejsca pamięci (non-lieux de mémoire),,'Teksty Drugie”2013, nr 1-2. Sontag S., O fotografii, tłum. S. Magala, Kraków 2009.

Szczerbakiewicz R., Archiwistyczny reportaż kryminalny. Retrokryminalna paraliteratura, ,Annales Universitatis Mariae Curie-Skłodowska" 2018, nr 2.

Sznajderman M., Fałszerze pieprzu. Historia rodzinna, Wołowiec 2016. 
Tołstoj L., Anna Karenina, tłum. K. Hłłakowiczówna, Warszawa 1965.

Ween L., Family Sagas of the Americas: «Los Sangurimas» and "A Thousand Acres», „The Comparatist" 1996, vol. 20.

Wolny-Zmorzyński K., Reportaż - jak go napisać? Poradnik dla słuchaczy studiów dziennikarskich, Warszawa 2004.

Wójcińska A., Perspektywa mrówki. Rozmowy z reporterami świata, Wołowiec 2015.

Zaremba Bielawski M., Dom z dwiema wieżami, tłum. M. Kalinowski, Kraków 2018.

Zatora A., Saga rodzinna - próba uporządkowania i konceptualizacji gatunku, ,Zagadnienia Rodzajów Literackich" 2017, z. 2.

Żórawska-Janik N., Nieustająca praca pamięci. «Fałszerze pieprzu» Moniki Sznajderman „ „Autobiografia" 2018, nr 2.

Żyrek-Horodyska E., Reportaż biograficzny czy biografia reportażowa? Refleksje genologiczne i analiza przypadku, ,Autobiografia" 2018, nr 2.

https://dowody.com/ksiazka/robert-rient-swiadek/ [dostęp: 6.01.2020].

\section{Reportażowa saga rodzinna. Fuzja gatunków i dziennikarska archiwistyka}

\section{Streszczenie}

W niniejszym artykule omówiona została reportażowa saga rodzinna - gatunek będący połączeniem dziennikarskiej sprawozdawczości z pamięciową narracją. Przedmiotem analiz uczyniono książki Fałszerze pieprzu Moniki Sznajderman oraz Dom z dwiema wieżami Macieja Zaremby Bielawskiego. Tomy te są przykładem osobliwego nurt pisarstwa non-fiction opierającego się na reporterskiej rekonstrukcji i osobistym zaangażowaniu autora. Celem artykułu jest przedstawienie reportażowej sagi rodzinnej jako struktury łączącej w sobie elementy powieści rodzinnej, autobiografii, eseju oraz reportażu. Jej cechą charakterystyczną jest dokonywana przez piszącego eksploracja przeszłości, do której dostęp zapośredniczony został poprzez dziennikarskie i pozadziennikarskie źródła informacji.

Słowa Kluczowe: Saga rodzinna, reportaż, historia rodzinna, Maciej Zaremba Bielawski, Monika Sznajderman

\section{Reportage family saga. The fusion of genres and journalistic archivistics}

\section{Abstract}

This article discusses the reportage family saga - a genre that combines journalistic reporting with memory narrative. In my research I focused on two books: Fałszerze pieprzu by Monika Sznajderman and Dom $z$ dwiema wieżami by Maciej Zaremba Bielawski. These books can be treated as examples of an autobiographical trend visible in the field of non-fiction writing. Both are based on the reporter's reconstruction and personal involvement of the author. The aim of the article is to present the reportage family saga as a complex structure combining elements of a family novel, autobiography, essay and reportage. The writer explores the past events and gains the access to them using journalistic and non-journalistic sources of information.

Key words: Family saga, reportage, family story, Maciej Zaremba Bielawski, Monika Sznajderman 